\title{
Land use/land cover change detection analysis using remote sensing and GIS of Dhanbad district, India
}

\author{
Ranjeet Kumar Singh ${ }^{1}$, Manmohan Singha ${ }^{1}$, Shailendra K. Singh ${ }^{1}$, Debjeet Pal ${ }^{1}$, \\ Nimisha Tripathi ${ }^{2 *}$ and Raj Shekhar Singh ${ }^{1}$ \\ ${ }^{1}$ Natural Resources and Environmental Management, CSIR-Central Institue of Mining and Fuel Research, \\ Barwa Road, Dhanbad, 826015, India. \\ *2 IU-CERI, University of Greenwich, Chatham Maritime, ME4 4TB, UK
}

Corresponding author: n.tripathi@gre.ac.uk

\begin{abstract}
Mining and human activities impacted the natural ecosystem leading to land use/land cover (LU/LC) change is of great concern by environmentalist and the society. The present study evaluated the LU/LC changes due to exploitation of coal in Dhanbad district of India during the period of 1987 to 2017. Remote sensing (RS) data indicated that out of 2043.32 ha LU/LC comprised of dense forest, low dense forest, open scrub, agriculture land, agriculture fallow, barren land, sand, river, water body, built-up and mining, constituted percent values of 8.17, $3.11,39.51,18.88,12.69,1.25,0.76,3.12,2.88,4.40$ and 5.22 in 1987 and 4.69, 6.01, 15.78, 41.36, 9.97, 3.90, $2.55,2.22,1.43,7.91,4.18$ in 2017 respectively. The LU/LC indicated that; for 30 years the percent share of dense forest, open scrub, agricultural fallow, river, water body and mining decreased by 42.63, 60.45, 21.47, 28.80, 50.37 and $19.85 \%$ respectively. Land use changes were due to harvesting of forest for fuel, shelter and agriculture, construction of residential houses in fallow land, urbanization and sand removal for construction material. The increase in low dense forest, agricultural land, barren land, sand and built-up area by 93.38, 119.06, 211.63, 234.96 and 79.85 percent respectively were due to shift of land use from forest to open scrub, agricultural fields and barren lands, new settlement by utilizing sands from river banks making the river stretch wider, open mine pits converted into water bodies in the district. These resulted in a considerable change in land use pattern in Dhanbad district, Jharkhand, India.
\end{abstract}

Keywords: Land use pattern; Change detection; Remote sensing data; GIS; Dhanbad; Jharkhand.

\section{Introduction}

Mining activities in the coal city of Dhanbad district date back to a century. Rapid growth in population and industrialization resulted in greater exploitation of natural resources to meet the basic human societal needs. To sustain the ever-growing requirement of magnified industrial activity, mining of fossil fuels, other essential ores and minerals have turned out to be a major activity (Tripathi et al., 2016). Due to unplanned mining before nationalization in 1974, ecological disturbances in and around mining areas in this district has been witnessed to a great extent. Rapid urbanization in Dhanbad has led to a drastic change in land use categories. For example, the boom in hard coke beehive plants, washeries, thermal power plants, construction activities for housing like residential flats and commercial complexes etc. The region consists of coal mines (103), coal washery (8), captive thermal power plants (3), beehive coke oven plants (126), soft coke plants (25), refractory plants (72), coke briquette plants (25), stone crushers (110) and brick kilns (118) (http://cpcb.nic.in). 
However, the need to meet the rising standard of living around the world has formed unfavourable impact on the environment and more so in the developing countries, like India which is striving to achieve the economic growth of $7.50 \%$ (www.tradingeconomics.com) for sustaining an ever-growing human population. It has resulted in over-exploitation of natural resources for different activities like deforestation, overgrazing, cultivation of marginal lands, mining and industrialization to meet the increasing demand for food, fuel and fiber (Areendran et al., 2013), influencing the topography, soil properties (Tripathi et al., 2009a), carbon storage, emission (Tripathi et al., 2014, 2016) and plant productivity. Therefore, the land use change can be one of the best tools to understand the changes occurring due to mining and other allied industrial activities.

Mining resulted in urban growth which leads to changes in land use and land cover (LULC) in many areas around the world, especially in developing countries including India. It is mandatory to study LULC for environmental clearance from the Ministry of Environment, Forest and Climate Change (MoEF\&CC), Govt. of India. Balak and Kolarkar (1993) and Rawat et al. (2013) stated that the LULC is a product of interface between society's cultural back ground, state and its substantial needs and the usual prospective of land. These are exaggerated by human interference and natural occurrence for example population growth, agricultural demand and trade, mining, urbanization, economic development, science and technology. Land use is the planned service of land management strategy placed on the land cover by human mediator or land administrator to utilize the land cover which replicates human actions such as industrial zones, residential zones, agricultural fields, grazing, sorting and mining (Zubair, 2006) and in another way the land cover is defined as the physical material on the earth's surface, including grass, asphalt, trees, bare ground, water, desert and ice and the immediate subsurface, including biota, soil topography, surface and groundwater. Further, it includes those structures created solely by human activities such as exposures and settlement (Lambin, et al., 2003; Baulies and Szejwach, 1997). This method involves comparing two independently produced classified land use/land cover maps from images of two different dates. It was found to be an accurate procedure for land use/land cover change detection; provided that the two land use/land cover maps had been accurately produced (Jensen, 1995; Singh, 1989). Therefore, information on LULC and potential for their most satisfying use is essential for selection, planning and completion of land use schemes to meet the growing burden for fundamental human need and benefits. Now a day's remote sensing (RS) and Geographic Information System (GIS) are best tools for monitoring land use changes.

The focus of the present study is a long-term change in LULC due to mining and allied industrial development along with urbanization and its impact on different ecosystems through remote sensing and GIS.

\section{Materials and methods Study area}

Dhanbad district is located in the Jharkhand State of India (Fig. 1). This area has been chosen for study due to a large number of mining activities, coal mine fire and massive population growth. It is the second most populated city in Jharkhand and ranked 42nd in most populated cities in India and sometimes referred as coal capital of India. The district has a total area of 2074 sq. km varying between $23^{\circ} 37^{\prime} \mathrm{N}$ to $23^{\circ} 03^{\prime} \mathrm{N}$ longitudes $86^{\circ} 06^{\prime} \mathrm{E}$ to $86^{\circ} 49^{\prime} \mathrm{E}$ latitude (http://jsac.jharkhand.gov.in). Dhanbad district lies in the mid-eastern part of Jharkhand state. Giridih bound it in the north, Bokaro in the west, Purulia in the south and Jamtara in the east (http://cgwb.gov.in). The drainage pattern of the area is controlled by Damodar River flowing west to east along the southern periphery and its tributaries viz. Jamunia, Khudia, Katri, Ekra, Tisra, Chatkari etc. 
The area has a tropical climate and is portrayed by very hot summer and cold winters. The period from May to June is very warm. The temperature in the cold weather months (November to February) varies from the lowest minimum of $8.3^{\circ} \mathrm{C}$ to the highest maximum of $34.4^{\circ} \mathrm{C}$. During summer months from March to June, the temperature varies from the lowest minimum of $13.3^{\circ} \mathrm{C}$ to the highest maximum of $47.0^{\circ} \mathrm{C}$. During the rainy season from July to October, the temperature varies from the lowest minimum $15^{\circ} \mathrm{C}$ to $36^{\circ} \mathrm{C}$. Relative humidity $(\mathrm{RH})$ is high in the rainy season from about $94 \%$ in June to $36 \%$ in May. Thunder storms usually occur in the month of May and June accompanied by temporary fall in temperature by a little degree. The area receives an annual rainfall of about 1100-1200 mm, out of which 75 to 80 percent of the annual rainfall occurs during the three months of June to September with little during winter months.

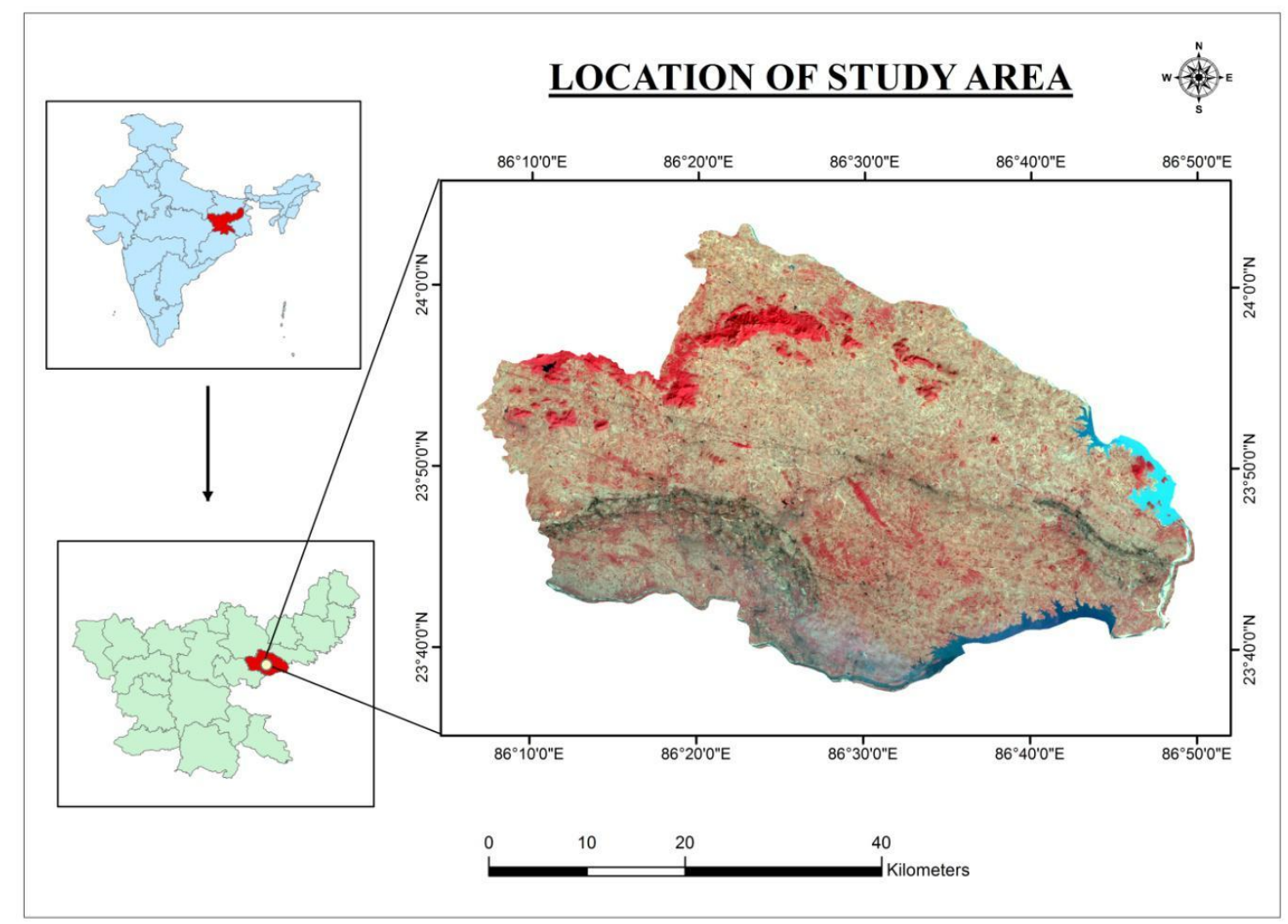

Figure 1. Location map of the study area.

\section{Material and Methods}

The data of LULC of the study area depended mainly on multi-temporal satellite images of 1997, 2009 and 2017 as shown in Fig. 3, 4 and 5. This was done through an incorporated coverage of landsat satellite images (MSS, TM, and ETM+) from the site of USGS Earth Resource Observation System Data Centre. Satellite images were geometrically rectified by Survey of India toposheet. As the images are of different path \& row, it was the first mosaic in the ERDAS imagine software. Area of interest was a subset of the image to carry out the further processes (LULC) and updated high-resolution spot, IRS to improve the accuracy of interpretation (Ibrahim et al., 2015). These images provide reliable and up to date information on changes of LULC over both space and time which may lead to establishing a trend on land cover change. The methodology used to get the result of a change in land use/land cover 
of Dhanbad district is through supervised classification of the Multi-Temporal Landsat satellite images. Different band combinations were applied to the image for better interpretation of the features and to collect the signatures (Table 1). Maximum likelihood method was taken to classify the pixel. Eleven classes were made based on the interpretation of satellite image. A field survey had been undertaken to check the accuracy of land cover classification and interpretation.

Table 1. Land use/land cover classification through satellite sensors and spacecraft

\begin{tabular}{|l|l|l|l|}
\hline PATH/row & Local acquisition date & \multicolumn{1}{|c|}{ Sensor } & Spacecraft \\
\hline $140 / 43 \& 140 / 44$ & $12-06-1987$ & TM & Landsat_5 \\
\hline $140 / 43 \& 140 / 44$ & $07-05-1997$ & TM & Landsat_5 \\
\hline $140 / 43 \& 140 / 44$ & $14-5-2017$ & OLI_TIRS & Landsat_8 \\
\hline
\end{tabular}

(Toposheet nos. 72L/8, 73I/1, 73I/2, 73I/5, 73I/6, 73I/8, 73I/9, 73I/10, 73I/13, 73I/14).

\section{Change Detection}

The LULC change detection study of Dhanbad district due to coal mining and allied industrial activity was carried out by suing LULC change model by flow chart mentioned in (Fig. 2). The image was downloaded from the Landsat-5 TM image and corrected by the image using ERDAS imagine software. Change detection was observed by calculating the area of same classes in different year LULC from ERDAS imagine 9.2. The area was calculated by attribute table of LULC layer. Positive or negative change in the area could be measured through the spatial variation in the study area represented by different colours. The methodology used to get the result of change in land use/land cover for Dhanbad

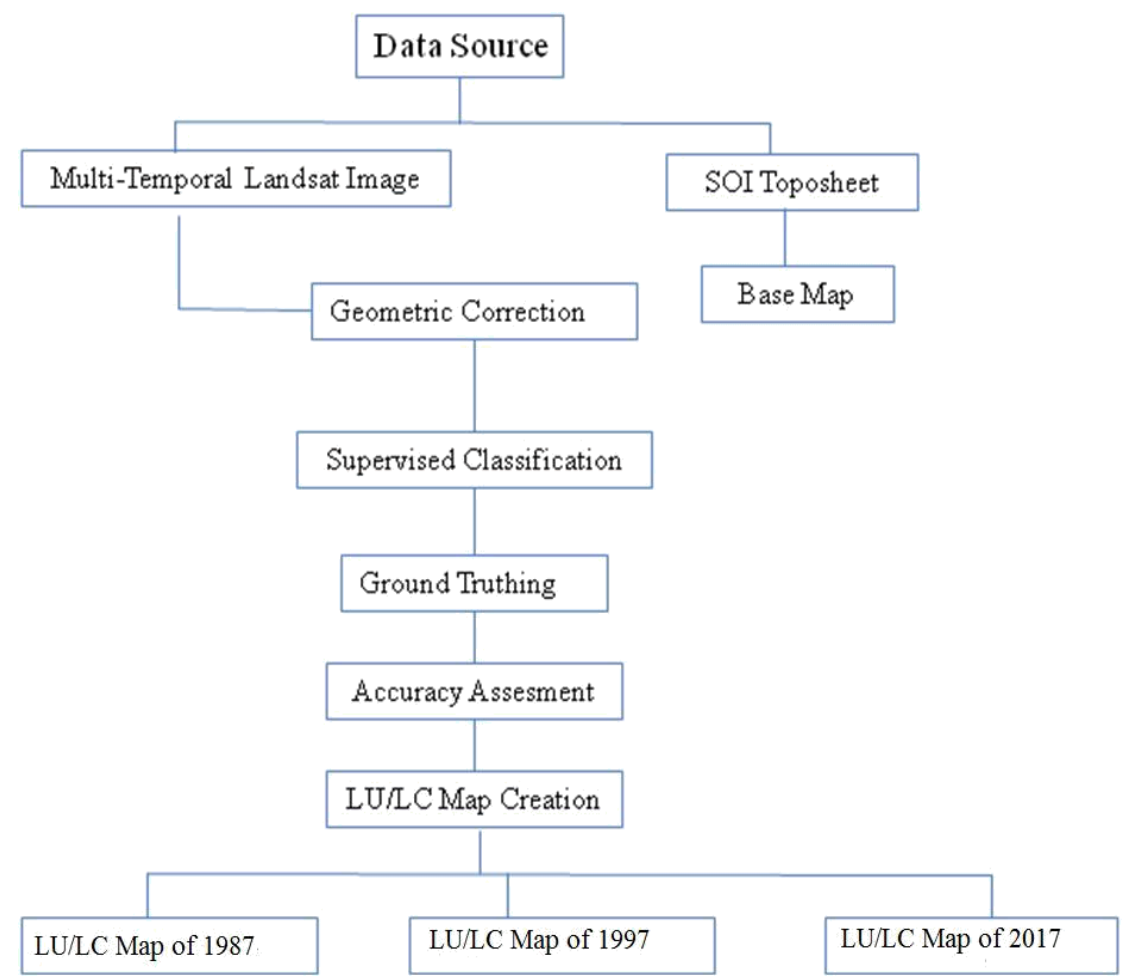

district was through supervised classification of the Multi-Temporal Landsat satellite images.

Figure 2. Flow chart of land use/land cover detection. 


\section{Results and discussion}

The data obtained through the incorporated coverage of Landsat satellite images (MSS, TM, and ETM+) and updated high-resolution spot, IRS to improve the accuracy of interpretation is given in Table 1 . The results of LULC status of three study periods i.e. 1987, 1997 and 2017 depicts land use land cover change in different categories like dense forest (DF), low dense forest (LDF), open scrub (OS), agricultural land (AL), agricultural fallow (AF), barren land (BL), sand (S), river (R), water body (WB), built-up (BU) and mining (M).

\section{Land use/land cover status}

In 1987, DF and LDF was 166.94 sq. $\mathrm{km}(8.17 \%)$ and 63.55 sq. $\mathrm{km}(3.11 \%)$, respectively of the total studied area while OS, AL, AF, BL, S, R, WB, BU and M were 807.32, 385.78, 259.3, 25.54, 15.53, $63.75,58.85,89.91$ and 106.66 sq. $\mathrm{km}$, which constitute $39.51,18.88,12.69,1.25,0.76,3.12,2.88,4.4$ and $5.22 \%$ respectively of the total geographical area (Table 2).

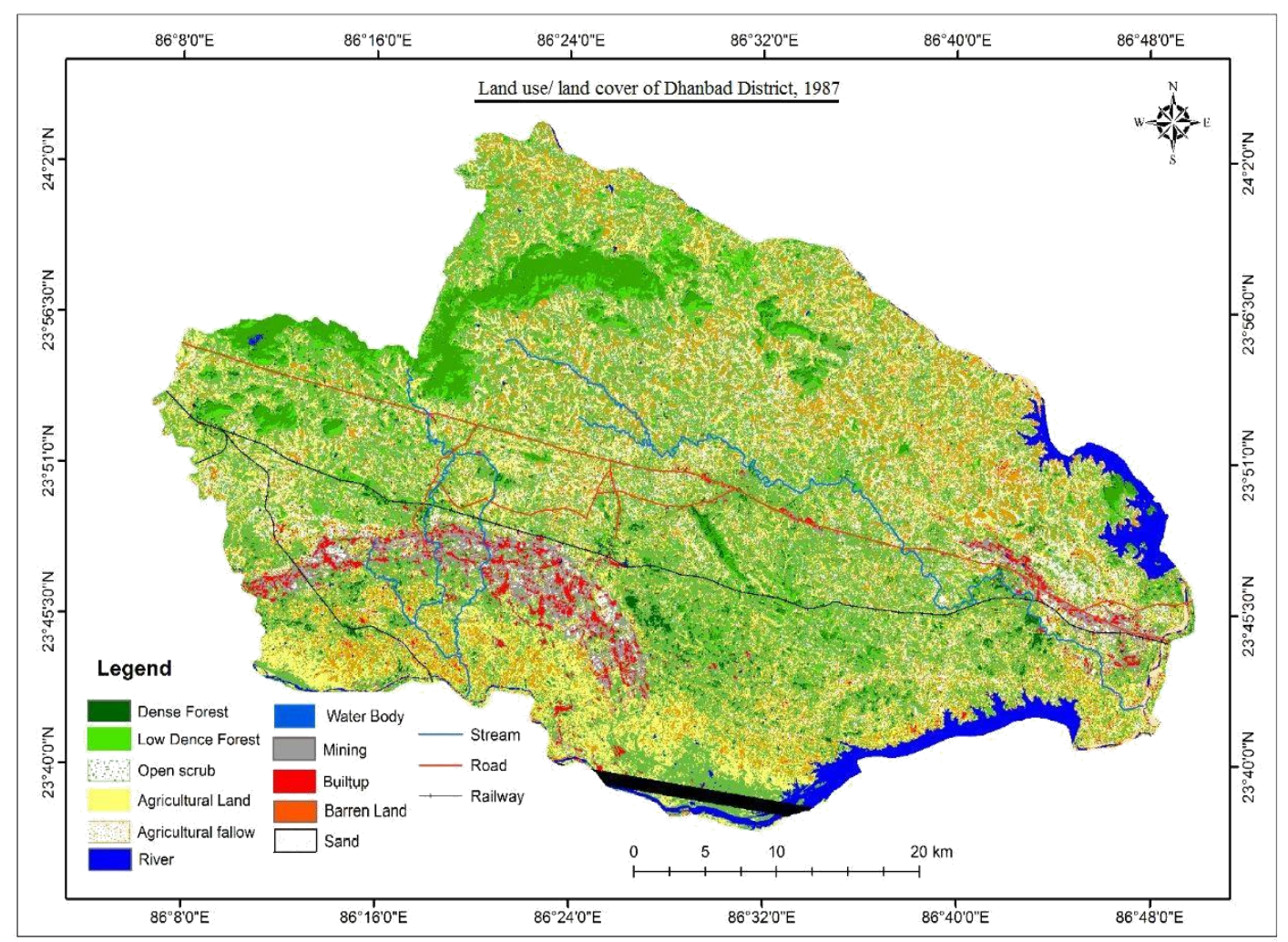

Figure 3. Land use/land cover of Dhanbad district during 1987.

In the year 1997, DF and LDF were 122.97 sq. $\mathrm{km}(6.02 \%)$ and 326.72 sq. $\mathrm{km}(15.99 \%)$ of the total area while OS, AL, AF, BU, M, R, WB, S and BL were 298.97, 721.39, 224.42, 69.07, 101.33, 37.41, $6.34,80.26$, and 54.43 sq. km constituting 14.63, 35.3, 10.98, 3.38, 4.96, 1.83, $0.31,3.93$ and $2.66 \%$ respectively of the total geographical area (Table 2). 


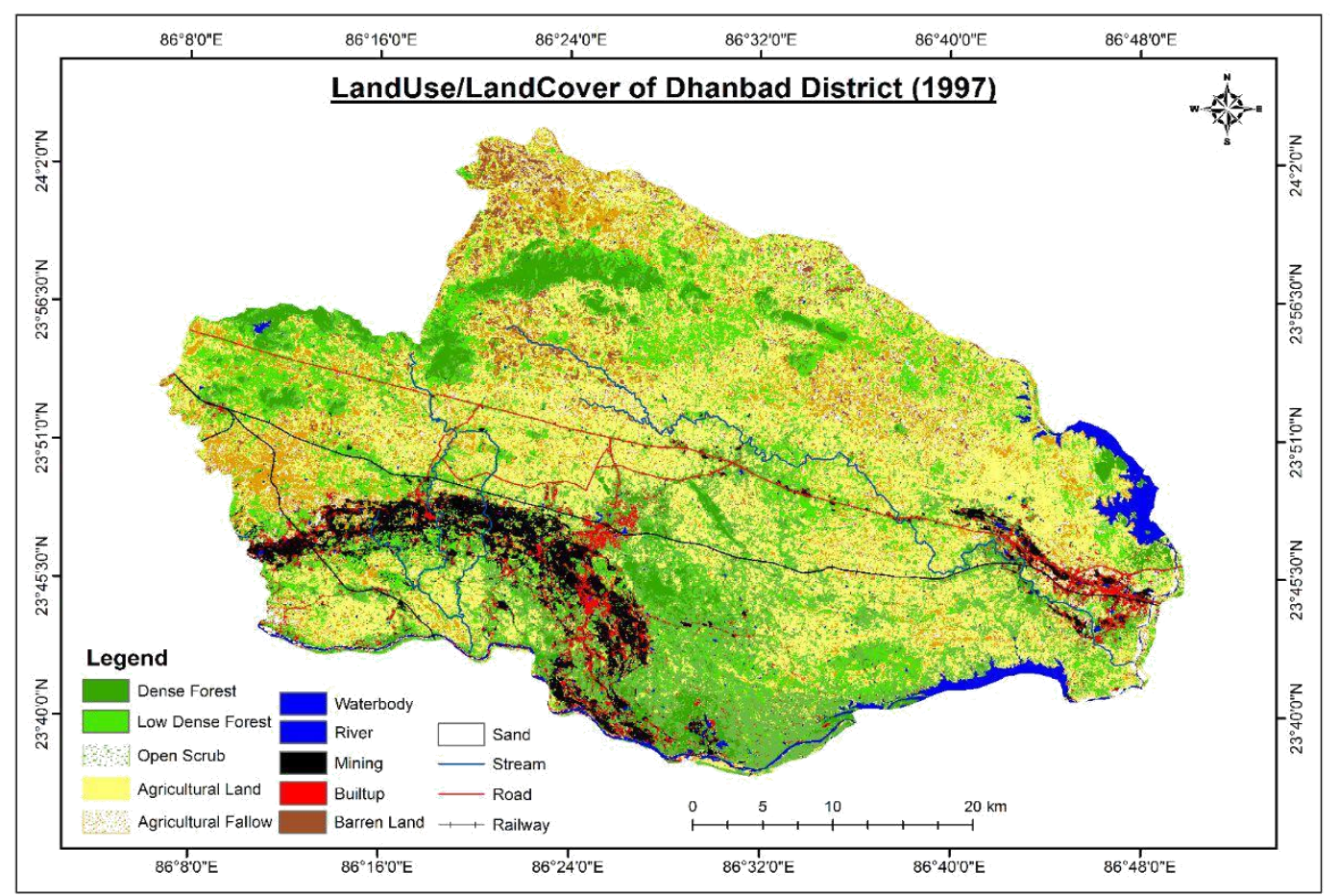

Figure 4. Land use/land cover of Dhanbad district during 1997.

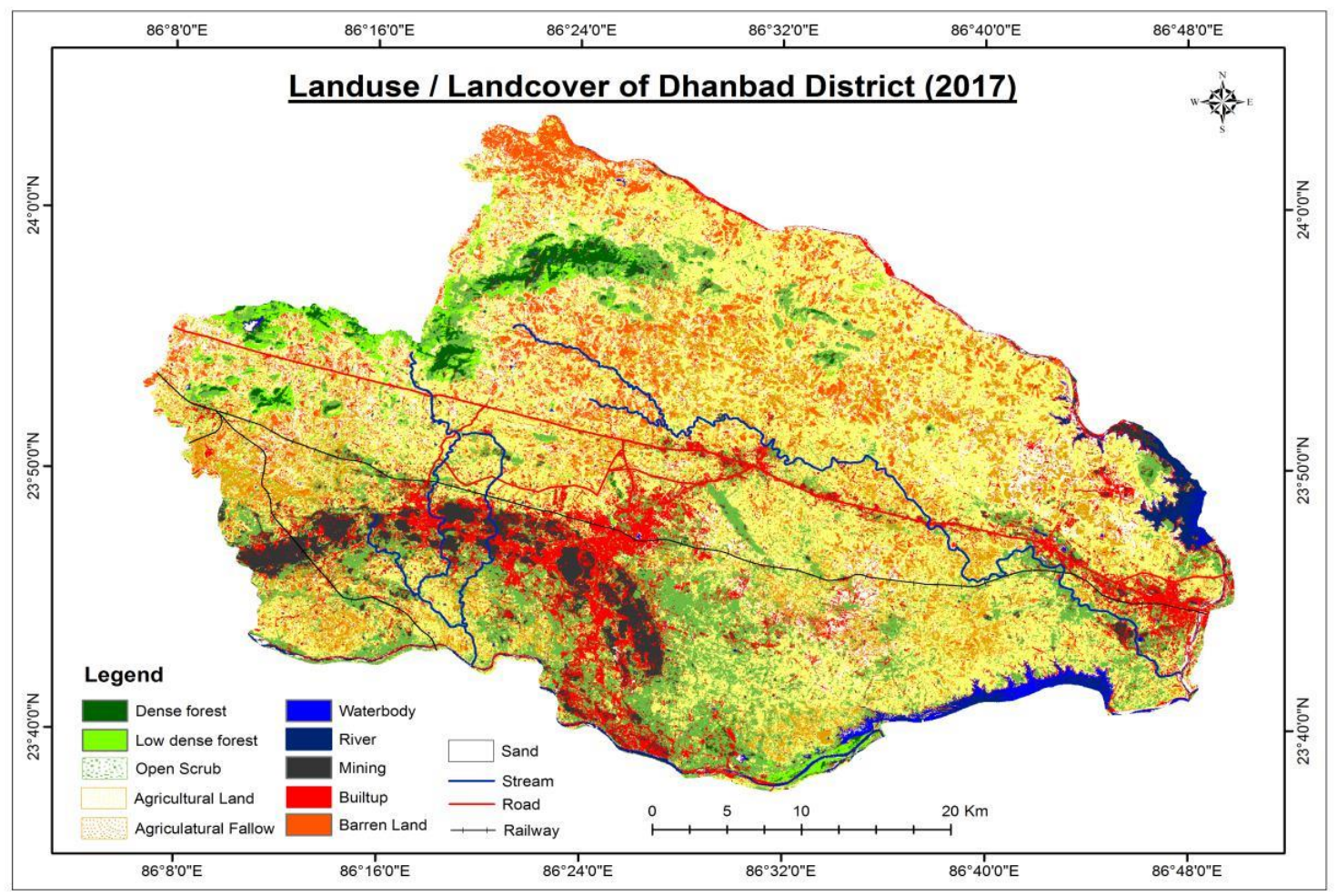

Figure 5. Land use/land cover of Dhanbad district during August 2017.

However, in 2017 status of DF, LDF, OS, AL, AF, BU, M, R, WB, S and BL were 95.78, 122.88, $322.54,845.08,203.64,161.70,85.49,45.39,29.21,52.02$ and 79.59 sq. km which constitute $4.69,6.01$, $15.78,41.36,9.97,7.91,4.18,2.22,1.43,2.55$ and $3.90 \%$, respectively of the total geographical area (Table 2). 
Table 2. Area under different land use categories and their percentage of the total area in Dhanbad district from 1987 to 2017.

\begin{tabular}{|c|c|c|c|c|c|c|c|c|c|}
\hline S.N. & Class Name & $\begin{array}{c}\text { Area } 1987 \\
\left(\mathbf{k m}^{2}\right)\end{array}$ & $\%$ & $\begin{array}{c}\text { Area } 1997 \\
\left(\mathrm{~km}^{2}\right)\end{array}$ & $\%$ & $\begin{array}{c}\text { Area } 2017 \\
\left(\mathbf{k m}^{2}\right)\end{array}$ & $\%$ & \begin{tabular}{|c|}
$2017-1987$ \\
$\left(\mathrm{~km}^{2}\right)$ \\
\end{tabular} & $\begin{array}{l}\text { Change } \\
\% \\
\end{array}$ \\
\hline 1 & Dense forest & 166.94 & 8.17 & 122.97 & 6.02 & 95.78 & 4.69 & -71.16 & -42.63 \\
\hline 2 & Low dense forest & 63.55 & 3.11 & 326.72 & 15.99 & 122.89 & 6.01 & 59.34 & 93.38 \\
\hline 3 & Open Scrub & 807.32 & 39.51 & 298.97 & 14.63 & 322.54 & 15.78 & -484.78 & -60.05 \\
\hline 4 & Agricultural Land & 385.78 & 18.88 & 721.39 & 35.3 & 845.08 & 41.36 & 459.3 & 119.06 \\
\hline 5 & Agricultural Fallow & 259.3 & 12.69 & 224.42 & 10.98 & 203.64 & 9.97 & -55.66 & -21.47 \\
\hline 6 & Barren Land & 25.54 & 1.25 & 54.43 & 2.66 & 79.59 & 3.9 & 54.05 & 211.63 \\
\hline 7 & Sand & 15.53 & 0.76 & 80.26 & 3.93 & 52.02 & 2.55 & 36.49 & 234.96 \\
\hline 8 & River & 63.75 & 3.12 & 37.41 & 1.83 & 45.39 & 2.22 & -18.36 & -28.80 \\
\hline 9 & Water body & 58.85 & 2.88 & 6.34 & 0.31 & 29.21 & 1.43 & -29.64 & -50.37 \\
\hline 10 & Built-up & 89.91 & 4.4 & 69.07 & 3.38 & 161.7 & 7.91 & 71.79 & 79.85 \\
\hline 11 & Mining & 106.66 & 5.22 & 101.33 & 4.96 & 85.49 & 4.18 & -21.17 & -19.85 \\
\hline & Total & 2043.13 & 100 & 2043.32 & 100 & 2043.32 & 100 & -- & -- \\
\hline
\end{tabular}
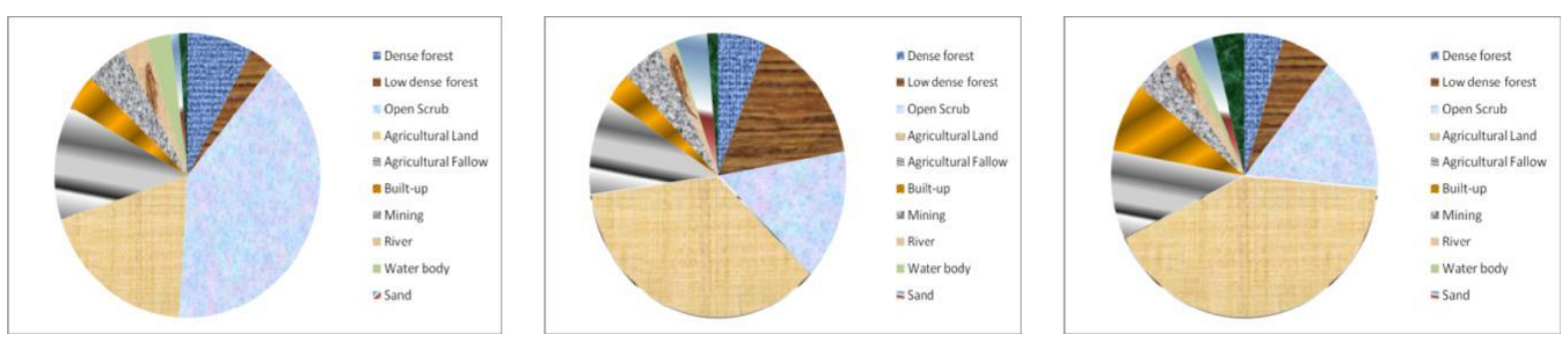

Figure 6. Pie-chart showing area under different categories of land use of Dhanbad during 1987, 1997 and 2017.

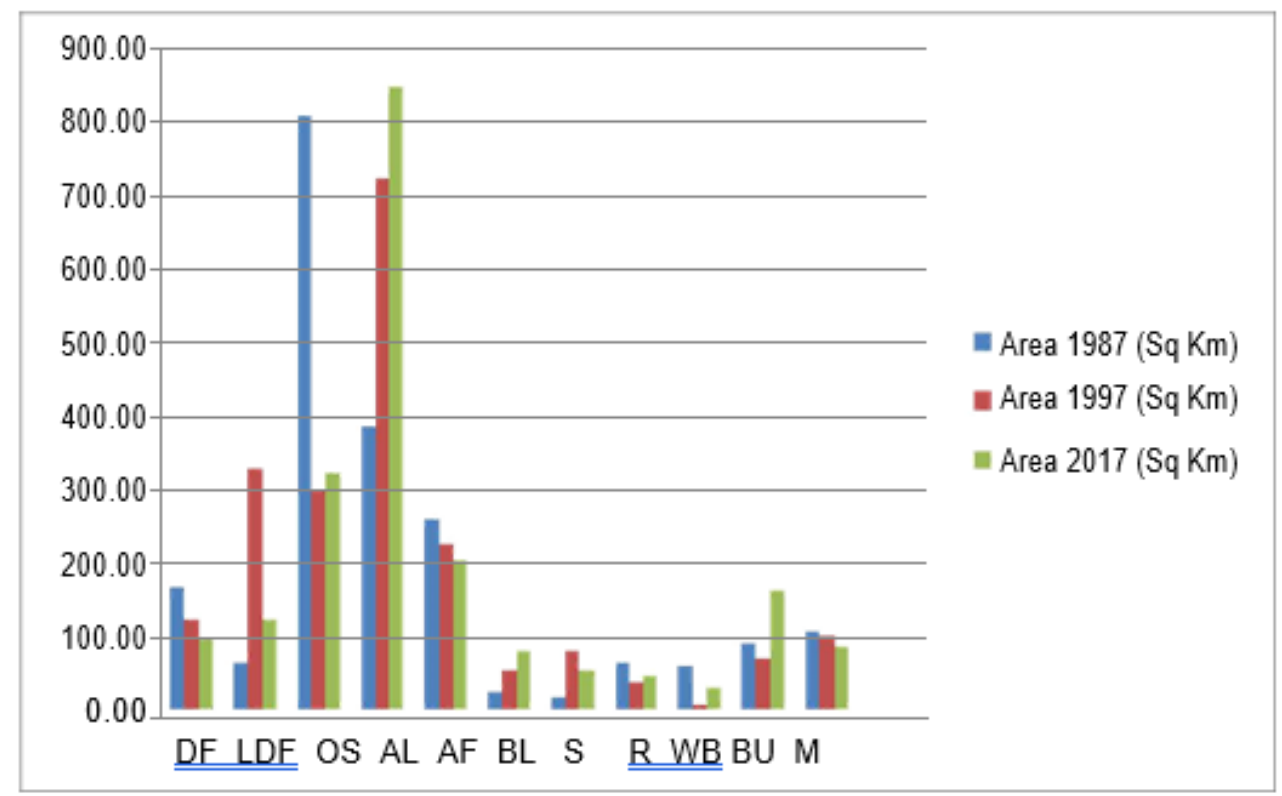

Figure 7. Comparative status of land use/land cover during 1987, 1997 and 2017 


\section{Change detection analysis}

The area under different land use/land cover categories and their comparative status are shown in Fig 6 and 7. The landsat image analysis revealed that the dense forest cover steadily decreases during the study period and the low dense forest showed a mixed trend, it initially increased during 1987-1997 from 63.55 to $326.72 \mathrm{sq}$. $\mathrm{km}$, and subsequently decreased during the period of 1997-2017 to levels of 122.89 sq. $\mathrm{km}$. The open forest cover was maximum during the period 1987-1997 and decreased to levels of 298.97 from 807.32 sq. $\mathrm{km}$ and in 2017 it marginally increased and stood at $322.54 \mathrm{sq} . \mathrm{km}$ (Fig. 8).

The steady decrease of dense forest over the study period was an indicator of the biotic pressure on forest resources and the increase in low dense forest in 1997, could be attributed to afforestation/conservation efforts (open scrub decreases between1987-1997); and partly to destruction/degradation of dense forests (dense forest cover decreases between1987-1997).

The share of agricultural land was steadily increased during the entire study period from 385.78 to 721.39 and finally to $845.08 \mathrm{sq}$. $\mathrm{km}$. This might be clearly attributed to conversion of forest to agricultural land (total forest cover decreased from 1037.81 to 748.66 and finally to $541.21 \mathrm{sq} . \mathrm{km}$ ) and to a small extent to the conversion of agricultural fallow back to agricultural land. Recently Singh et al. (2017) reported a decrease of herbaceous ground cover due to mining activity.

The relationship between sand and barren land on one hand and water body and rivers on the other could be largely explained by abiotic factors like anthropogenic reasons and filling of open cast pits with rainwater storage. The deposition of sand and silt on riverbed is enhanced due to soil runoff deposition resulting in decrease of river width. The increase in the barren land is also attributable to the increase in mined out wasteland areas and spread of mine fire area leading to the destruction of vegetation.

The substantial increase in built-up area was due to the destruction of forest land, conversion of agricultural land and was triggered reduction of water bodies (filling up of water bodies and conversion to built-up areas).

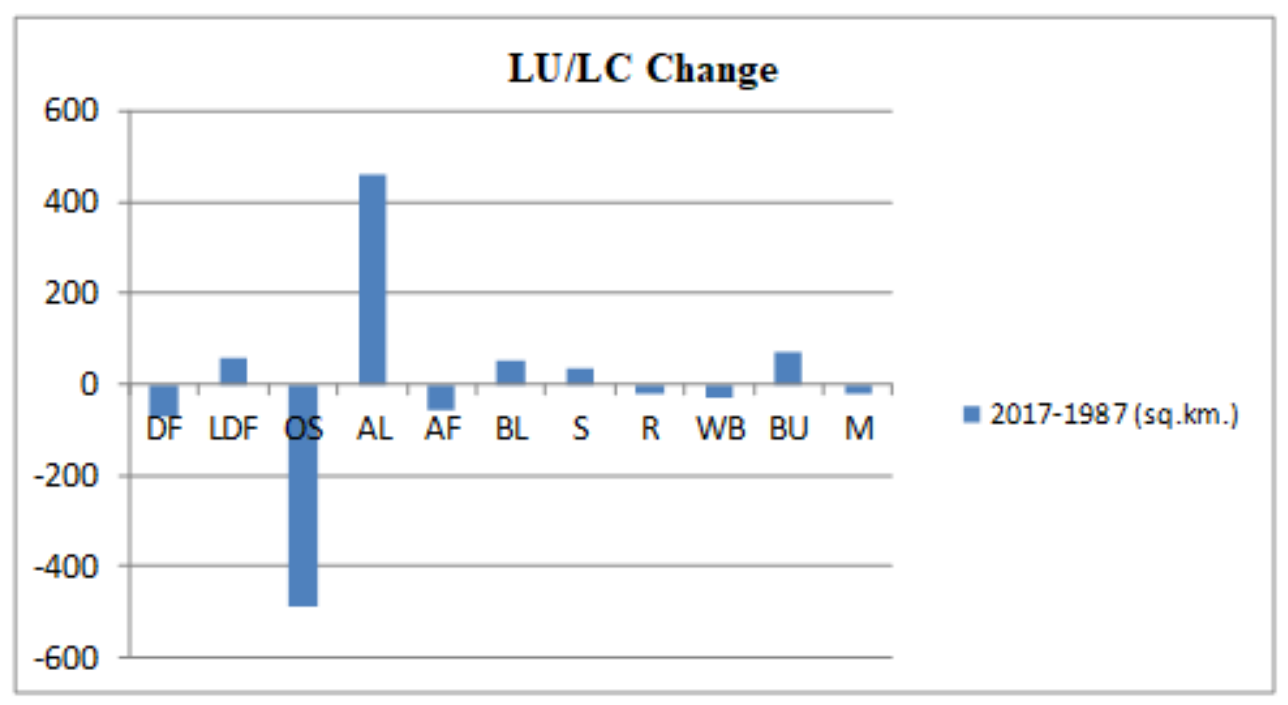

Figure 8. Percent land use change detection from 1987-2017. 
The land use change revealed that $\mathrm{DF}, \mathrm{OS}, \mathrm{AF}, \mathrm{R}$ and $\mathrm{M}$ were decreased during the study period by 42.63, 60.05, 21.47, 28.80, 50.37 and $19.85 \%$ and LDF, AL, BL, S and BU increased by 93.38, 119.06, 211.63, 234.96 and $79.85 \%$ respectively (1987-2017) (Fig. 8).

The hierarchical cluster analysis was successfully used to classify the per cent land use changes during twenty years (1997-2017) and produced three different clusters. The first cluster contains AL, R, OS, AF, M, DF, S, BL and LDF and the second cluster contains BU linked to $S$ and the third cluster contain only WB. This could be interpreted as the maximum changes occurred in the third cluster followed by second and minimum changes found in the first cluster (Fig. 9).

Rescaled Distance Cluster Combine

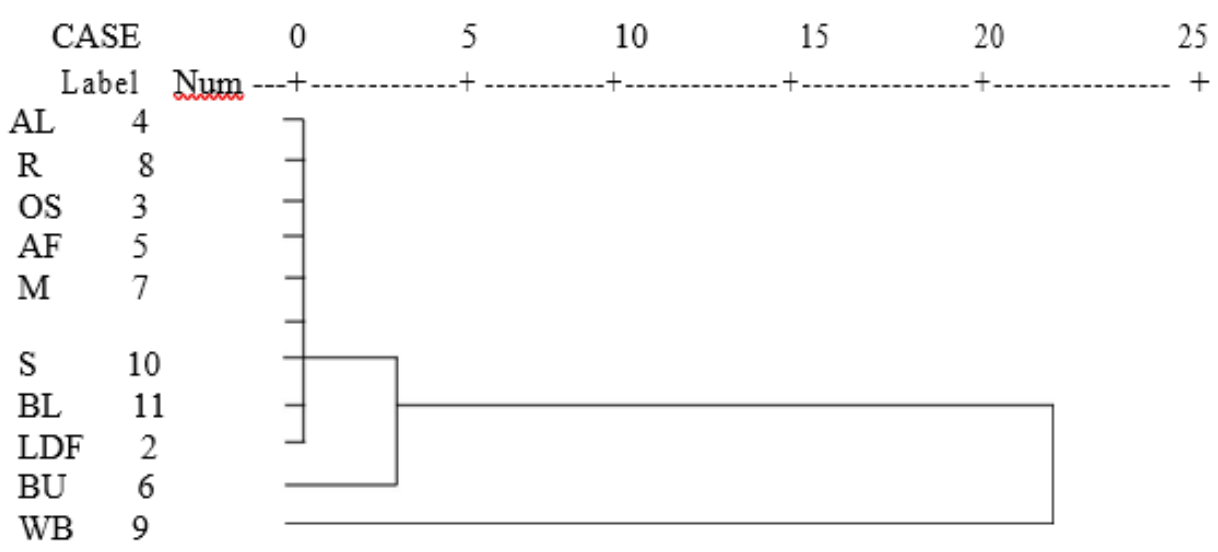

Figure 9. Hierarchical dendrogram showing clustering of percent land use change from 1997 to 2017.

The hierarchical cluster analysis was carried out to classify the per cent land use changes during thirty years (1987-2017) and produced three clusters. The first cluster contains R, M, WB, DF, AF, LDF, BL, $\mathrm{BU}$ and $\mathrm{S}$ and the second cluster contains AL linked to F; and the third cluster contains only OS. This could be interpreted as the maximum negative change occurred in the third cluster (OS) followed by a maximum positive change in the second cluster (AL) and minimum changes found in first cluster group (Fig. 10).

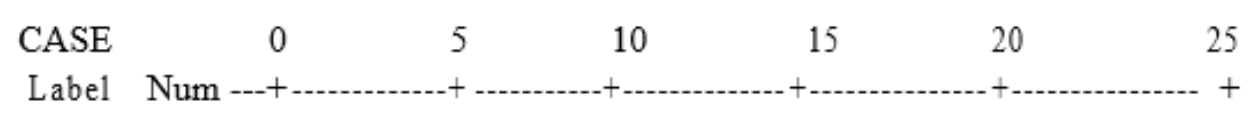

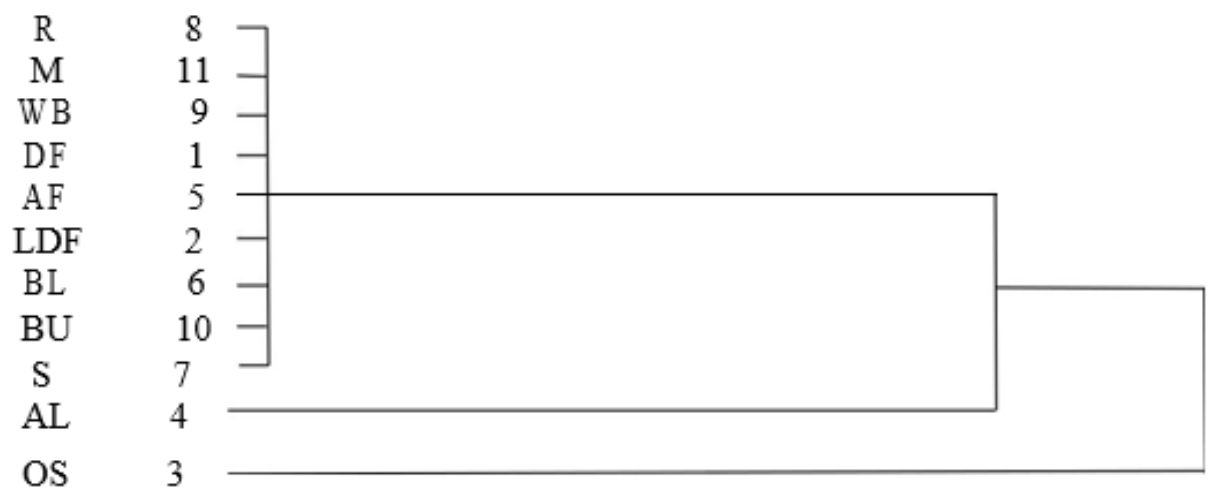

Figure 10. Hierarchical dendrogram showing clustering of percent land use change from 1987 to 2017. 
According to Usman et al. (2015) several changes in the land use pattern have occurred in Dhanbad district and were visible from processed landsat images (Fig 3, 4 and 5). Heavy reliance on agricultural production and increasing population was the main cause of several changes occurring in landuse pattern. These changes necessitate the availability of improved and updated LULC datasets (Wardlow et al., 2007) for effective planning and production management, thus facilitating both farmers and policy makers (Liang et al., 2013). Martha et al. (2010) reported that mining activities caused disturbances in several land use categories such as AF, LDF, and OS and WB in several parts of Jharia Coalfield of Dhanbad. There are several aspects of the LULC changes in Dhanbad district in which opencast mining is the most important resulting change in the natural topography of the area (Ghosh, 1989; Rathore and Wright, 1993; Tripathi et al., 2009b). Prakash and Gupta, (1998), CMPDI (2010) opined that decrease in DF by 3.5\% was due to mining from 1997 to 2017. Our study indicated the decrease was due to rapid growth in population and mining both and the increase was due to afforestation activities initiated by mining \& forest departments due to corporate social responsibility and inherent pressure from legislative bodies.

Saini et al. (2016) stated that Jharia Coalfields (JCF) of Dhanbad district had undergone many changes that have remodelled its face. Open cast mines have led to changes in topography due to the creation of OB dumps. During rainfall, runoff from these OB dumps caused degradation of land and disruption of water flow. Coal fire areas had expanded and increased the temperature of the ground surface thus making it unsuitable for plant and animal species and posed a health hazard to local inhabitants.

\section{Conclusion}

Present study detected significant changes in land use and land cover from 1987 to 2017. The land area under LDF, AL, BL, S and BU increased while DF, OS, AF, R, WB and M decreased. The increase in LDF by $98.38 \%$ was due to conservation/afforestation efforts and partly by conversion of dense forest. There was a substantial increase in AL by $119.06 \%$ was due to the diversion of mostly open scrub, forest land and agricultural fallow for agriculture purposes by the local villagers. The open scrub markedly decreased due to expanding population consequently built up area has enhanced. The increase in the barren land is attributable to the increase in mined out wasteland areas and expanding mine fired area changing the scrubland into the barren area. The increase in built-up area has led to destruction of forest land, conversion of agricultural land and also has triggered reduction of water bodies (landfill on water bodies and conversion to built-up areas). Thus, the present study illustrated that Digital Thematic Mapper (TM), Digital Enhanced Thematic Mapper (ETM) and Digital IRS-P6 LISS-III are crucial technologies to identify the land use and land cover change detection analysis of Dhanbad district.

There is need of enhancement of forest area due to dwindling of life support system (vegetation) for the biological organism, hence the mine managers and local inhabitants should pay attention for forest protection and to reduce the air, water pollution in the coal capital of India.

\section{References}

Areendran, G., Rao, P., Raj, K., Mazumdar, S., Puri, K., 2013. Land use/land cover change dynamics analysis in mining areas of Singrauli district in Madhya Pradesh, India. Tropical Ecology. 54(2), 239-250.

Balak, R., Kolarkar, A.S., 1993. Remote sensing application in monitoring land use changes in arid Rajasthan. Int. J. Remote Sens. 14 (17), 3191-3200. 
Baulies, X., Szejwach, G., 1997. LUCC Data Requirements Workshop Survey of Needs, Gaps and Priorities on Data for Land-Use/ Land-Cover Change Research Organized by IGBP/IHDP-LUCC and IGBP-DIS, Barcelona, Spain.

CPMPDI, report, 2010. Land use/land cover mapping of Jharia Coalfield on satellite data for the year 2008. Report submitted to Coal India Limited in March 2010.

Ghosh, R., 1989. Mining in Jharia coalfield, Eastern India: An estimation of its impact index Journal Geological society of India. 33, 253-360.

http://cgwb.gov.in/District_Profile/Jharkhand/Dhanbad.pdf accessed 12 August, 2016.

http://cpcb.nic.in/divisionsofheadoffice/ess/DHANBAD.pdf accessed 12 August, 2016.

http://jsac.jharkhand.gov.in/Report_PDF/Land_Degradation/Land_Degradation_Report_Final .pdf, Dated 19 December 2016. National land degradation mapping project of Jharkhand state using multitemporal satellite data. pp 37.

Ibrahim, H.H., Elfaig A.H.I., J. Mokhtar, Egemi O., Abdelklreim, M., 2015. Land use/Land Cover detection in semi-arid lands: a study from Sudan-Ghubayash area: A GIS and remote sensing perspective. International journal of scientific and technology research. 4

(5), 124-131.

Jensen, J.R., 1995. Introductory Digital Image Processing: A Remote Sensing Perspective. 2 edn, Prentice Hall PTR, Upper Saddle River, NJ, USA.

Lambin, E.F., Geist, H.J., Lepers, E., 2003. Dynamics of land use/ cover change in tropical regions. Annual Review of Environment and Resources. 28, 205-241.

Liang, L., Gong, P., 2013. Evaluation of global land cover maps for cropland area estimation in the conterminous United States. International Journal of Digital Earth. 1-16. doi: 10.1080/17538947.2013.854414.

Martha, T. R, Guha, A., Kumar, K.V, Kamaraju, M.V.V., Raju, E.V.R. 2010. Recent coal fire and land - use status of Jharia coalfield, India from satellite data. International journal of Remote sensing. 31 (12), 32433262 .

Prakash, A., Gupta, R.P., 1998. Land-use mapping and change detection in a coal mining area- a case study in the Jharia coalfield, India. International Journal of Remote sensing. 19 (3), 391-410.

Rathore, C.S., Wright, R., 1993. Monitoring environmental impacts of surface coal mining. International Journal of Remote Sensing. 14, 1021-1042.

Rawat, J.S., Biswas, V. Kumar, M., 2013. Changes in land use/land cover using geospatial techniques: A case study of Ramnagar town area, district Nainital, Uttarakhand, India. The Egyptian Journal of Remote Sensing and Space Sciences. 16, 111-117.

Saini, V., Gupta, R.P., Arora, M.K., 2016. Environmental impact studies on coalfields in India: A case study from Jharia Coal-field. Renewable and Sustainable Energy Reviews. 53, 1222- 1239.

Singh, A., 1989. Digital change detection techniques using remotely sensed data. International Journal of Remote Sensing. 10(6), 989-1003.

Singh, R.S, Singh, R.K., Bera, S., 2017. Impact of mining on the herbaceous ground cover and wild fauna in Birsha-Damoh forest range of Malanjkhand copper mines of India. Eurasian Journal of Forest Science. 5(1), $1-7$ 
Tripathi, N., Singh, R.S., 2009a. Influence of different land uses on soil nitrogen transformations after conversion from an Indian dry tropical forest. Catena. 77, 216-233.

Tripathi, N., Singh, R.S., Singh, J.S., 2009b. Impact of post-mining subsidence on nitrogen transformation in Southern Tropical Dry Deciduous Forest, India. Environmental Research. 109 (3), 258-266.

Tripathi, N., Singh, R.S., Hills, C.D., 2016. Soil carbon development in rejuvenated Indian coal mine spoil. Ecological Engineering. 90, 482-490.

Tripathi, N., Singh, R.S., Nathaniel, C.P., 2014. Mine spoil acts as a sink of Carbon dioxide in Indian Dry Tropical Environment. The science of the Total Environment, Elsevier, 468-469, 1162-1171.

Usman, M., Liedl, R., Shahid, M.A., Abbas, A., 2015. Land use/Land cover classification and its change detection using multi-temporal MODIS NDVI data. Journal of Geographical sciences. 25 (12), 1479-1506. DOI: $10.1007 / \mathrm{s} 11442-015-1247-\mathrm{y}$

Wardlow, B.D., Egbert, S.L., Kastens, J.H., 2007. Analysis of time-series MODIS 250 m vegetation index data for crop classification in the U.S. Central Great Plains. Drought

Mitigation Centre Faculty Publications. Paper 2. http://digitalcommons.unl.edu/droughtfacpub/2

www.tradingeconomics.com/india/gdp-growth-annual. accessed 12 August, 2016.

Zubair, A.O., 2006. Change detection in land use and Land cover using remote sensing data and GIS: a case study of Ilorin and its environs in Kwara State, MSc Thesis, University of Ibadan, Nigeria.

Submitted: 10.03 .2018

Accepted: 29.05 .2018 